Danijela Rajić ${ }^{* 1}$, Ljubica Vasiljević ${ }^{1}$, Dragan Tošković ${ }^{1}$, Zoran Obrenović, Miladin Gligorić ${ }^{1}$

${ }^{1}$ University of East Sarajevo, Faculty of Technology, Zvornik, Bosnia and Herzegovina, ${ }^{2}$ Alumina Ltd, Zvornik, Bosnia and Herzegovina
Scientific paper ISSN 0351-9465, E-ISSN 2466-2585 UDC:620.192.4/.6 doi: $10.5937 /$ ZasMat1704564R

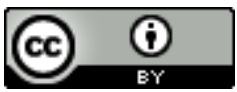

Zaštita Materijala 58 (4)

564 - 569 (2017)

\title{
Influence of crystalization temperature on morphological properties of dibutylphtalate alumosilicate adsorbents
}

\begin{abstract}
Alumosilicates have advantages over other adosrbents because they have high adsorption capacity and high selectivity. Due to this fact, the paper investigates the synthesis and characterization of the aluminosilicate materialused as a potential adsorbent of dibutyl phthalate (DBP) The following analyses were conducted on the samples synthesized at various crystallization temperatures $\left(70,80\right.$ and $\left.90^{\circ} \mathrm{C}\right)$ : the adsorption of DBP, crystallinity (XRD), medium particle diameter (Ds50\%) and scanning electron microscopy (SEM) It has been found that the aluminosilicate species obtained at temperatures of 80 and $90 \mathrm{C}$ have good adsorbent properties for $D B P$ The medium particle diameter varied depending on the crystallization temperature according to the principles of autocatalytic nucleation and the "memory effect" of the gel. At the temperature of $90^{\circ} \mathrm{C}$, crystallinity decreases significantly (37.87\%) whereas dibutylphthalate adsorption increases due to the increase in the content of other nonzeolite species.
\end{abstract}

Keywords: morphological properties, aluminosilicates, adsorption, dibutyl phthalate.

\section{INTRODUCTION}

Phthalic acid is the main degradation product of a type of compounds called phthalic esters, such as dimethyl phthalate (DMP), diethyl phthalate (DEP), dibutyl phthalate (DBP), di-(2-ethylhexyl phthalate) (DEHP), di-isononyl phthalate (DINP), benzylbutyl phthalate (BBP) and di-n-octyl phthalate (DNOP). These compounds support the conversion of polyvinyl chloride (PVC) from a completely solid to the elastic form which makes them excellent plasticizers [1]. However, they can cause serious disorders in the endocrine system, so, the efficient removal of phthalic acid from wastewaters is very significant [2] from the aspect of the environment protection and protection of people's health.

PVC is a material with widespread applications, including those in the manufacture of toys and other children's products. Phthalates represent $69 \%$ of plasticizers in use in the USA, $92 \%$ in

\footnotetext{
${ }^{*}$ Corresponding author: Danijela Rajić

E-mail: danijela_rajic@hotmail.com

Paper received: 01. 09. 2017.

Paper accepted: 05. 10. 2017.

Paper is available on the website:

www.idk.org.rs/journal
}

Western Europe and $81 \%$ in Japan. They represent $82 \%$ of the 2.5 million tons of plasticizers used in these three regions. The European Union has prohibited the use of DBF, DEHF, BBF for the production of baby toys, and DNOF for products that children could put in their mouths. Other countries, including the USA, Japan, Denmark, Argentina and Mexico, have also prohibited the use of phthalates for the production of toys [3]. Phthalates are found in the air, food, in humans and are released from PVC by surface contact, especially when using mechanical pressure $[1,4]$. Children's toys containing $10-40 \%$ of phthalates of their total weight are subjected to testing for their potentially bad health effects. DBP is a colorless.slightly odored,fluid-like oil,, with poor conductivi. It iswater insoluble but soluble in mineral oils, hexanes and most organic solvents making them easily soluble in bodil fluids, such as plasma [5].

Adsorption is considered to be one of the most desirable ways of removing phthalates from water. Because of all this, adsorbents undoubtedly play an important role in the adsorption process. Alumosilicates have advantages over other adsorption agents because they not only have high adsorptive capacity but also exhibit high selectivity $[6,7,8]$. 
<smiles>CCCCCOC(=O)c1ccccc1C(=O)OCCCC</smiles>

Figure 1. Structure of DBP [5]

Slika 1. Struktura DBP [5]

The use of aluminosilicates as phthalate adsorbents is based on the following features:

- the fact that they are characterized by regular pores with defined openings which allows separation of molecules by their size;

- the fact that there is a difference in the rate of diffusion of molecules into the alumosilicate pores;

- adsorption equilibrium is determined by electrostatic forces involving dipolar and quadropolar interactions as well as dispersion forces. In the aluminosilicates with a high content of zeolite $A$ and $X$ type aluminium, where the negative charge on the skeleton is compensated by an appropriate number of cathodes, electrostatic interactions are predominant $[6,7]$.

In order to determine the potential for adsorption of DBP and its connection to the aluminosilicate particle properties, the hydrothermal ("hydro-gel") process was used for the synthesis of samples taken from the raw materials at the temperature of $90^{\circ} \mathrm{C}$, which crystalized at the temperatures of 70,80 and $90^{\circ} \mathrm{C}$ respectively. The synthesized samples were analysed in order to determine the following parameters: changes in the crystal phase (XRD), dibutyl phthalate adsorption (DBP), particle size (Ds50\%) and scanning electron microscopy (SEM) [9].

\section{EXPERIMENTAL PART}

\subsection{Synthesis of zeolite}

The process of aluminosilicate synthesis involved the use of the aluminate solution prepared in the laboratory by dissolving $\mathrm{Al}(\mathrm{OH})_{3}$ hydrate in $50 \% \mathrm{NaOH}$ in which $\mathrm{Al}_{2} \mathrm{O}_{3}$ concentration ranged between 100 and $120 \mathrm{~g} / \mathrm{L}$ and $\mathrm{Na}_{2} \mathrm{O}$ concentration between 140 and $170 \mathrm{~g} / \mathrm{L}$

The silicon required for the syntheses was taken from sodium-silicate (water glass) obtained from the process of production in "Alumina Ltd". The $\mathrm{SiO}_{2}$ concentration in this glass ranged between 378 and $389 \mathrm{~g} / \mathrm{L}$, while the $\mathrm{Na}_{2} \mathrm{O}$ concentration ranged between 160 and $170 \mathrm{~g} / \mathrm{L}$. In addition to these raw materials, distilled water was also used in the syntheses

From these raw materials in laboratory conditions, Several samples were synthesized by the hydrogel method, with the temperature of the raw materials of $90^{\circ} \mathrm{C}$ and the temperature of crystallization of 70,80 and $90^{\circ} \mathrm{C}$ respectively. The synthesis was conducted in such way as to satisfy the following molar ratios, $\mathrm{SiO} 2 / \mathrm{Al} 2 \mathrm{O} 3=$ 1.88; $\mathrm{Na} 2 \mathrm{O} / \mathrm{Al} 2 \mathrm{O} 3$ = 4.2; $\mathrm{H} 2 \mathrm{O} / \mathrm{Al} 2 \mathrm{O} 3$ = 90; $\mathrm{H} 2 \mathrm{O}$ $/ \mathrm{Na} 2 \mathrm{O}=25$. This molar ratio was selected for the purpose of synthesizing 4A zeolite aluminosilicates.

\subsection{Characterization of the manufactured zeolite}

Adsorption of dibutyl phthalate (DBP) was performed by an internal method, at synthesized powder of aluminosilicate, dried 2 hours at $105^{\circ} \mathrm{C}$ with instilment DBP on room temperature [10]. DBP produced by Vita Him from Russia, with a density of $1.05 \mathrm{~g} / \mathrm{cm}^{3}$, was used for the analysis.

The particle size as well as their medium diameter (Ds50\%) were determined on the laser particle size BA INSTRUMENTS, "MicroSaizer$201 \mathrm{C}$, in the range of $0-50 \mu \mathrm{m}$ and 30 seconds of sonication at $50 \mathrm{~W}$ ultrasonic strength.

The degree of crystallinity $r$ (XRD) was determined using the PHILIPS PW 1710 diffractometer by means of the $\mathrm{Cu}$ anti-cathodes $(40 \mathrm{~V}, 50 \mathrm{~mA}, \mathrm{~K} \alpha=0.15405 \mu \mathrm{m})$. The samples were recrded in the $2 \theta$ range of 5 to $40^{\circ}$, and the results were processed using the software for the automatic powder diffraction (PC-APD) and the ICDD / JCPDS PDF-2 database.

Scanning electron microscopy (SEM) was performed usingJEOL JSM 6460LV device, whereas BAL-TEC, SCD 005 Sputer Coaltar was used for sample preparation.

\section{RESULTS AND DISCUSSION}

The crystallization temperature for the given molar ratio of the reactants ranged from 70 to 90 ${ }^{\circ} \mathrm{C}$, with an increase of $10^{\circ} \mathrm{C}$ in each successive synthesi (Table 1). At higher crystallization temperatures $\left(80\right.$ and $\left.90^{\circ} \mathrm{C}\right)$, the synthesized zeolite samples exhibited greater dibutyl phthalate adsorption proprties due to the fact that, during the nucleation at higher crystallization temperatures more nuclei are formed that are able continue the crystallization process, resulting in an increased porosity of the particles formed in such way. In addition to this fact, medium particle diameter (Ds $50 \%$ ) was 4.77 and $3.89 \mu \mathrm{m}$, successively for these temperatures (Table 1). 
Table 1. Physico-chemical properties of alumosilicates obtained at different crystallization temperatures

Tabela 1. Fizičko-hemijske osobine alumosilikata dobijenih na različitim kristalizacionim temperaturama

\begin{tabular}{|c|c|c|c|c|}
\hline $\begin{array}{c}\text { Number of } \\
\text { synthesis }\end{array}$ & $\begin{array}{c}\text { Crystallization } \\
\text { temperature }\left[{ }^{\circ} \mathrm{C}\right]\end{array}$ & $\begin{array}{c}\text { Adsorption of DBP } \\
{\left[\mathrm{cm}^{3} / \mathrm{g} \text { powder] }\right.}\end{array}$ & $\begin{array}{c}\text { Degree of } \\
\text { crystallinity, [\%] }\end{array}$ & $\begin{array}{c}\text { Medium diameter of } \\
\text { particles } \mathrm{D}_{\mathrm{s}} 50 \%,[\mu \mathrm{m}]\end{array}$ \\
\hline 1 & 70 & 0,90 & 67,75 & 5,16 \\
\hline 2 & 80 & 1,10 & 48,24 & 4,77 \\
\hline 3 & 90 & 1,20 & 37,87 & 3,89 \\
\hline
\end{tabular}

The relative crystallinity of the synthesized samples was measured relative to the standard zeolite sample A "Degussa". The relative crystallinity in these samples ranged from $37.87 \%$ to $67.75 \%$. Obviously, the samples were crystalline, but the crystal phase fraction decreased in the samples obtained by syntheses number 2 and 3 , which also shows the intensity of these peaks on the X-ray difractograms of the obtained alumosilicate (Figures 2, 3, 4). At the same time, , we notice that with the reduction of the crystal phase, the peak intensity of $12^{\circ} \theta$ and $22^{\circ} \theta$ increases, which corresponds to hydrosodalite.

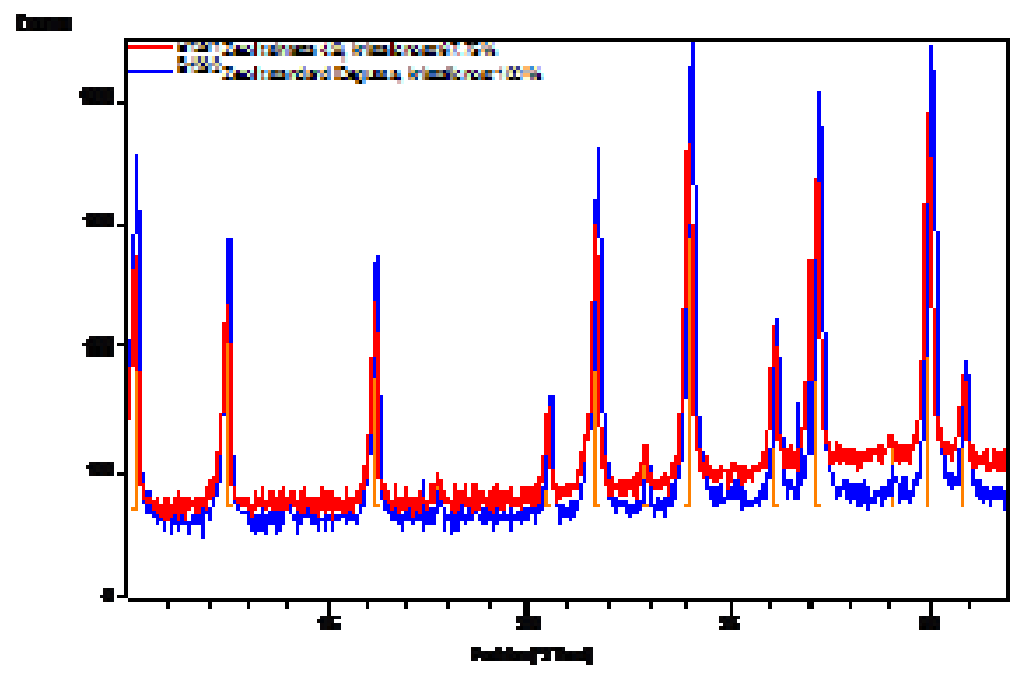

Figure 2. $X R D$ diffractogram of alumosilicate obtained at $70^{\circ} \mathrm{C}$

Slika 2. XRD difraktogrami alumosilikata dobijenog na $70^{\circ} \mathrm{C}$

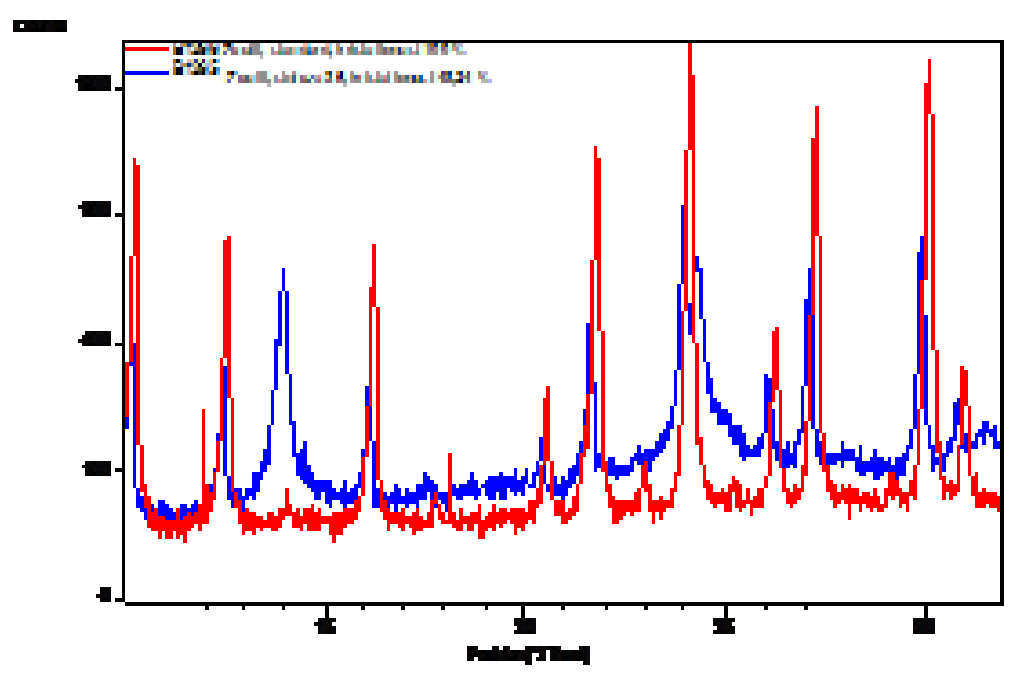

Figure 3. XRD diffractogram of alumosilicate obtained at $80^{\circ} \mathrm{C}$

Slika 3. XRD difraktogrami alumosilikata dobijenog na $80^{\circ} \mathrm{C}$ 
The obtained X-ray difractograms from synthesis number 2 , indicates that the temperature of $80^{\circ} \mathrm{C}$ gave a product having a crystallinity of $48.24 \%$ (Figure 3 ). At higher crystallization temperatures $\left(80{ }^{\circ} \mathrm{C}\right.$ ), crystallization (, apart from the formation of zeolite $\mathrm{A}$, hydrosodalite was also formed, which contributes to the increase of the degree of adsorption of dibutyl phthalate (1.10$1.20 \mathrm{~cm}^{3} / \mathrm{g}$ zeolite) (Table 1).

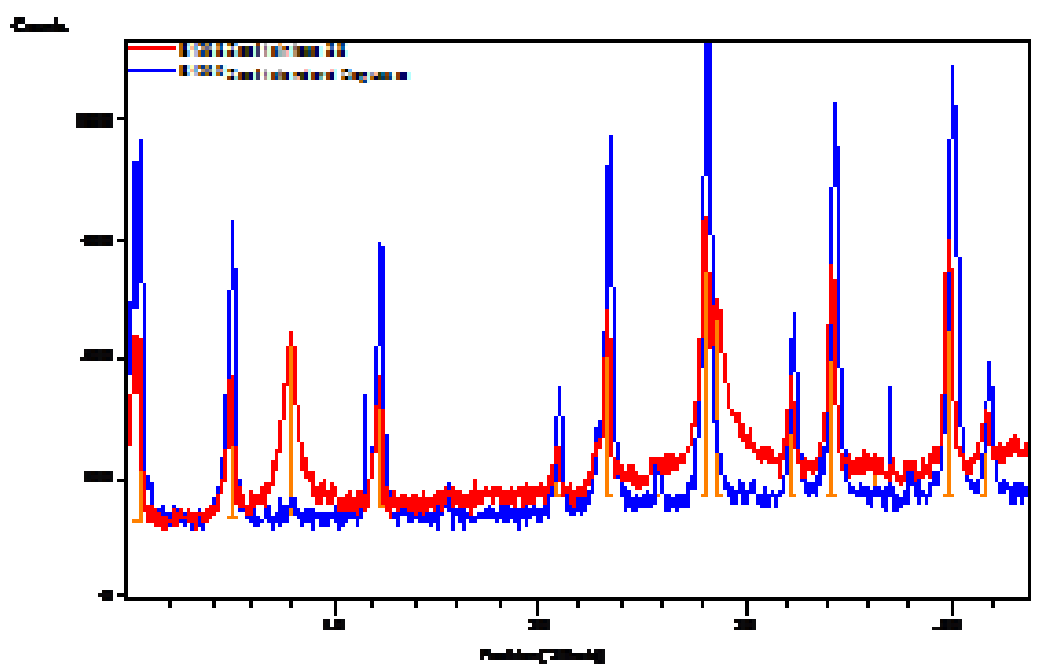

Figure 4. XRD diffractogram of alumosilicate obtained at $90^{\circ} \mathrm{C}$

Slika 4. SEM snimci alumosilikata dobijenog na $90^{\circ} \mathrm{C}$

At a lower crystallization temperature, $70^{\circ} \mathrm{C}$, dibutylphthalate adsorption is lower $-0.90 \mathrm{~cm}^{3} / \mathrm{g}$ of alumosilicate. The direct dependence of the crystalline phase fraction on the crystallization temperature could not be proven, althouh it ranged from $67.75 \%$ to $37.87 \%$ (Figure 2-4). SEM images of the zeolite obtained under the above-mentioned synthesis conditions, given in Figures. 5, 6, 7 respectively indicate that absorption and DBP results depend on the particle size and the mean particle diameter [6].

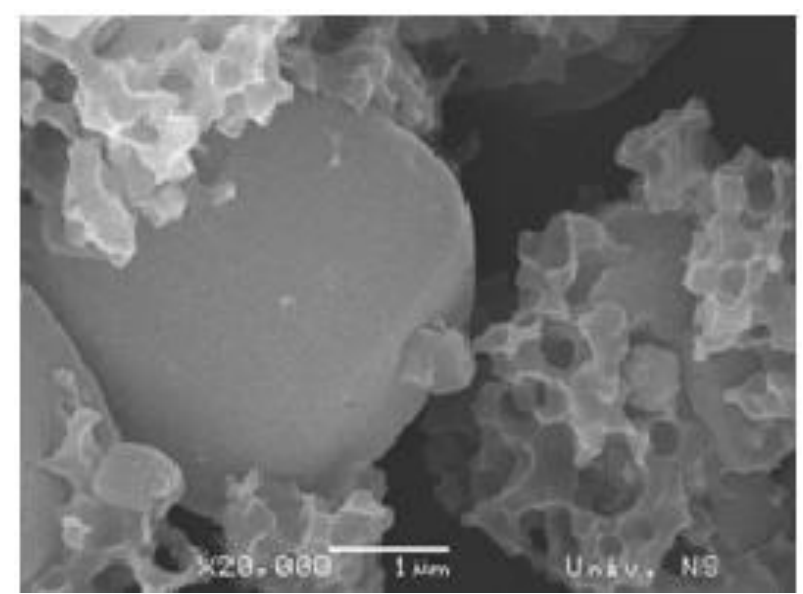

Figure 5. SEM micrograph of alumosilicate obtained at $70^{\circ}$

Slika 5. SEM snimci alumosilikata dobijenog na $70^{\circ} \mathrm{C}$
The fact that a sample having a crystallinity of $67.75 \%$ was obtained at the temperature of $70^{\circ} \mathrm{C}$ indicates that the dominant phase is zeolite $A$, which also confirms the SEM analysis of this sample (Figure 5). The particle size of the synthesized samples is similar in most of the tested systems at all crystallization temperatures, which is in accordance with the principles of autocatalytic nucleation and the "memory effect" of the gel.

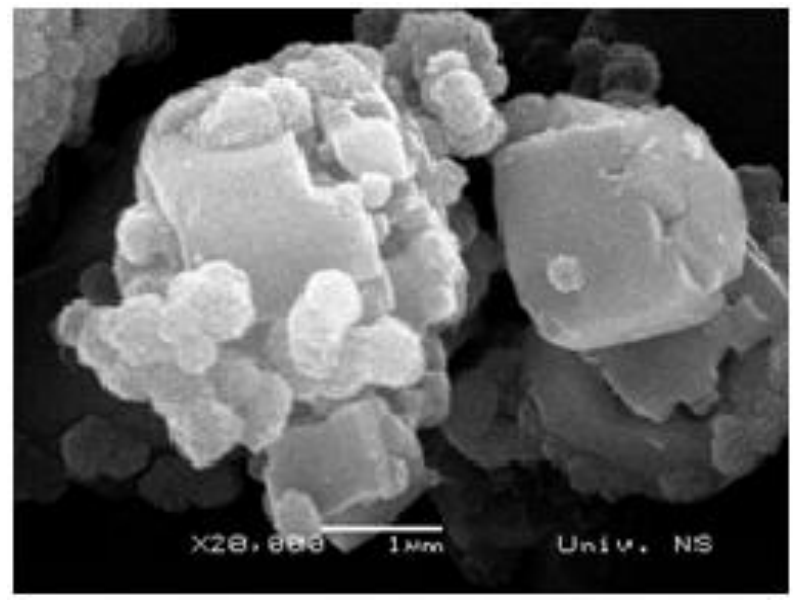

Figure 6. SEM micrograph of alumosilicate obtained at $80^{\circ} \mathrm{C}$

Slika 6. SEM snimci alumosilikata dobijenog na $80^{\circ} \mathrm{C}$ 


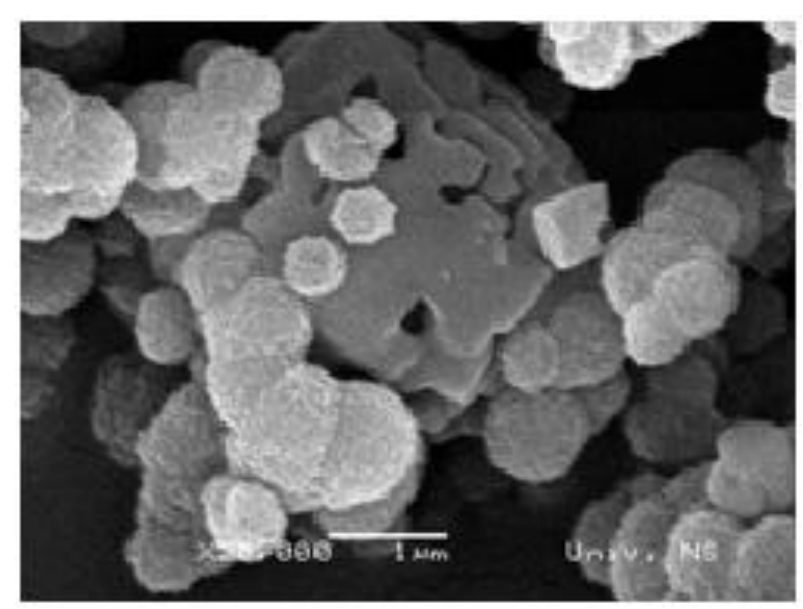

Figure 7. SEM micrograph of alumosilicate obtained at $90^{\circ} \mathrm{C}$

\section{Slika 7. SEM snimci alumosilikata dobijenog na} $90^{\circ} \mathrm{C}$

The observed dependences of the analyzed systems that were obtained by the "hydro-gel" method were confirmed by the research conducted by the "dry-gel" method of the group of authors in China [9]. Relative crystallinity in these systems also showed direct temperature dependence, which also evident from SEM images [6].

\section{CONCLUSION}

The amount of adsorbated dibutyl phthalate depends on the crystallization temperature of the aluminosilicate. Higher temperatures of crystallization $\left(80\right.$ and $\left.90^{\circ} \mathrm{C}\right)$, resulted in the formation of zeolite $\mathrm{A}$ and hydrosodalite. In the synthesized samples, adsorbation of dibutylphthalate was between 1.10 and $1.20 \mathrm{~cm}^{3} / \mathrm{g}$ of zeolite (Table 1). At a lower crystallization temperature $\left(70^{\circ} \mathrm{C}\right)$, the adsorbation of dibutyl phthalate is lower - 0.90 $\mathrm{cm}^{3} / \mathrm{g}$ of zeolite. We can also conclude that the morphology of the formed particles is directly dependent on the crystallization temperature.

The relative crystallinity of the product obtained by synthesis could not be proved to be directly dependent on the crystallization temperature, although it ranged from 67.75 to $37.87 \%$. Medium particle diameters (Ds50\%) are similar in most analyzed systems at all crystallization temperatures, which is in accordance with the principles of autocatalytic nucleation and the "memory effect" of the gel. In accordance with the conclusions of these studies, the pore size, chemical composition of the resulting powders, moisture and other quality parameters of the formed alumosilicate (JIK et al.) should be further investigated in order to find the optimum temperature of the aluminosilicate synthesis to be used as a more favorable DBP adsorbent. The temperature has a direct effect on the polymerization reactions of reactive silicates, aluminates and aluminosilicate species. The temperature affects several parameters in the synthesis: the change of the aluminosilicate phase as well as the induction period prior to crystallization. The induction period decreases with increasing temperature $[8,9]$.

\section{REFERENCES}

[1] C.Wang, X.Yan, M.Zhou, X.Hu, Z.Ni (2016) Metalazolate framework-6-for fast adsorption removal of ftalic acid from aqueous solution, Journal of Molecular Liquids, 223, 427-430.

[2] J.D.Mendez-Diaz et all (2012) Adsorption/ bioadsorption of phtalic acid, an organic micropollutant present in landfill leachates, on activated carbons, Journal Colloid Interface Sci., 369, 358-365.

[3] S.Johnson, N.Saikia, R.Sahu (2010) Phtalates in Toys, Centre for science and environment, New Delhi, India.

[4] E.Atlas, S.C.Ciam (2001) Global transport of organic pollutants: ambient concentrations in remote marine atmospheric, Science, 211, 163-165.

[5] file:///C:/Users/PC034/Downloads/A1041.pdf (12.06.2017).

[6] D.Rajić, Lj.Vasiljević, D.Tošković, M.Gligorić, Z.Obrenović (2017) Sinteza i karakterizacija alumosilikata kao potencijalnog adsorbensa dibutilftalata, V International Congress Engineering, Ecology and Materials in processing Industry, 15-17 march, Jahorina, Republic of Srpska.

[7] S.Chakravarti, A.Gupta, B.Hunek (2001) First National Conference on Carbon Sequestration, plenare lecture, Washington DC, USA.

[8] I. Wilaiporn, K. Rangsriwatananon (2012) Morphology-Controlled Synthesis of Zeolites and Physicochemical properties, Engineering Journal, 16(3), 241-249.

[9] L. Xing-Dong et all (2013) Influence of synthesis parameters on $\mathrm{NaA}$ zeolite crystals, Powder Technology, 243, 184-193.

[10] Internal method MA.ZIB-P020, Alumina Ltd, Zvornik, B\&H. 


\title{
IZVOD
}

\section{UTICAJ TEMPERATURE KRISTALIZACIJE NA MORFOLOŠKE KARAKTERISTIKE ALUMOSILIKATNIH ADSORBENASA DIBUTILFTALATA}

\begin{abstract}
Alumosilikati imaju prednosti u odnosu na druga adsorpciona sredstva jer pokazuju visok adsorpcioni kapacitet $i$ visoku selektivnost. Zbog ove činjenice, izvršena je sinteza i karakterizacija alumosilikatnog materijala koji se može koristiti kao potencijalni adsorbens dibutilftalata (DBF). Ispitana je adsorpcija DBF-a na alumosilikatu sintetisanom pri različitim temperaturama kristalizacije $\left(70,80\right.$ i $\left.90^{\circ} \mathrm{C}\right)$, praćena je njegova kristaličnost $(X R D)$, srednji prečnik čestica $\left(D_{s} 50 \%\right)$, a urađena je i skenirajuća elektronska mikroskopija (SEM) sintetisanih uzoraka. Utvrđeno je da na temperaturama od 80 i $90^{\circ} \mathrm{C}$ dobijamo alumosilikatne vrste koje po svojim osobinama mogu poslužiti kao dobri adsorbensi DBF-a. Srednji prečnik čestica kretao se zavisno od temperature kristalizacije u skladu sa principima autokatalitičke nukleacije $i$ „efekta pamćenja“ gela. Na temperaturi kristalizacije od $90^{\circ} \mathrm{C}$ kristaličnost znatno pada i iznosi $37,87 \%$ dok adsorpcija dibutilftalata raste na račun povećanja udjela drugih nezeolitnih vrsta.
\end{abstract}

Ključne reči: morfološke osobine, alumosilikati, adsorpcija, dibutilftalat.

\section{Naučni rad}

Rad primljen: 01. 09. 2017.

Rad prihvaćen: 05. 10. 2017.

Rad je dostupan na sajtu: www.idk.org.rs/casopis

(C) 2017 Authors. Published by Inženjersko društvo za koroziju. This article is an open access article distributed under the terms and conditions of the Creative Commons Attribution 4.0 International license (https://creativecommons.org/licenses/by/4.0/) 